\title{
Crystallization differentiation of melt in the mushroom-shaped plume head
}

\author{
Anatoly Kirdyashkin ${ }^{1}$, and Alexey Kirdyashkin ${ }^{1,2, *}$ \\ ${ }^{1}$ V.S. Sobolev Institute of Geology and Mineralogy, Siberian Branch of the Russian Academy \\ of Sciences, pr. Akademika Koptyuga 3, Novosibirsk, 630090, Russia \\ ${ }^{2}$ Novosibirsk State University, ul. Pirogova 2, Novosibirsk, 630090, Russia
}

\begin{abstract}
The influence of crystallization differentiation on the compositional changes in melt of the mushroom-shaped plume head has been clarified. According to our calculations, crystallization differentiation produces residual melt composition approaching the composition of the normal granites.
\end{abstract}

\section{Introduction}

The compositional changes in melt of the plume head is determined by stages: 1) after settling of refractory minerals; 2) after settling of plagioclase in the melt subsequent to the first stage. Crystallization differentiation proceeds under thermal and hydrodynamic conditions described in our previous paper [1]. The compositional change is analyzed using the estimates on the bulk composition of continental crust proposed by A. Ronov and A. Yaroshevsky [2]. The normative mineral composition is calculated according to the CIPW method using the MS Excel worksheet (author: G. Stern, Orlean, France).

\section{Calculations of melt composition}

Let us determine the melt composition after the settling of unmelted (refractory) minerals. Consider the melt drawn from the plume conduit to the plume roof. At the melt temperature $T_{\text {melt }}=1410^{\circ} \mathrm{C}$ the refractory minerals (RM) remain in the form of suspended solids in the melt volume. The following minerals will remain unmelted (Table 1, column 1): diopside (Di), hyperstene (Hyp), magnetite (Mgt), ilmenite (Ilm), apatite (Ap). The melt consists of orthoclase (Or), albite (Ab) and anorthite (An) components. On the average, the density of $\mathrm{RM}$ is approximately $25 \%$ above the melt density. Thus, the solid particles (crystallites) of RM will settle to the base of the plume head (Fig. 1A). The settling time of RM is $10-$ 1600 years. Normative quartz Qtz (tridymite, $13.6 \%$ ) (Table 1, column 2) also remains as solid phase. Its density is lower than the melt density. Thus tridymite will float to the plume roof and will be suspended in the free-convection flows of the plume head.

Next the percent composition of the oxides comprising the solid phase (RM) is to be determined. We shall exemplify determination of the percent composition of oxides in

* Corresponding author: aak@igm.nsc.ru 
diopside $(\mathrm{Di}=8.9 \%)$. The chemical formula of diopside can be represented in the form of oxides: $\mathrm{CaO} \cdot \mathrm{MgO} \cdot 2 \mathrm{SiO}_{2}$. Molecular weight of diopside is $M_{\mathrm{Di}}=216.6$. The percent composition of the oxides for Di is given in Table 2.

Table 1. The composition of melt in the plume head for $T_{\text {melt }}=1410^{\circ} \mathrm{C}$.

\begin{tabular}{|c|c|c|c|c|c|}
\hline \multicolumn{6}{|c|}{ In the form of oxides } \\
\hline 1 & 2 & 3 & 4 & 5 & 6 \\
\hline Oxide & $\begin{array}{c}\text { Bulk } \\
\text { composition } \\
\text { by }[2][\%]\end{array}$ & $\begin{array}{c}\text { After } \\
\text { settling of } \\
\text { RM [\%] }\end{array}$ & $\begin{array}{c}\text { The melt } \\
\text { layer }\left(l_{\text {melt }}\right) \\
{[\%]}\end{array}$ & $\begin{array}{c}\text { After settling } \\
\text { of plagioclase } \\
{[\%]}\end{array}$ & $\begin{array}{c}\text { The melt } \\
\text { layer } \\
\left(l_{\text {melt }}^{\prime}[\%]\right.\end{array}$ \\
\hline $\mathrm{SiO}_{2}$ & 59.3 & 43.9 & 65.3 & 41.9 & 76.1 \\
\hline $\mathrm{TiO}_{2}$ & 0.7 & 0.0 & 0.0 & 0.0 & 0.0 \\
\hline $\mathrm{Al}_{2} \mathrm{O}_{3}$ & 15.0 & 13.9 & 20.6 & 7.5 & 13.7 \\
\hline $\mathrm{Fe}_{2} \mathrm{O}_{3}$ & 2.4 & 0.0 & 0.0 & 0.0 & 0.0 \\
\hline $\mathrm{FeO}$ & 5.6 & 0.0 & 0.0 & 0.0 & 0.0 \\
\hline $\mathrm{MnO}$ & 0.1 & 0.1 & 0.2 & 0.1 & 0.2 \\
\hline $\mathrm{MgO}$ & 4.9 & 0.6 & 0.9 & 0.0 & 0.0 \\
\hline $\mathrm{CaO}$ & 7.2 & 4.5 & 6.8 & 1.4 & 2.5 \\
\hline $\mathrm{Na}_{2} \mathrm{O}$ & 2.5 & 2.3 & 3.4 & 1.6 & 2.9 \\
\hline $\mathrm{K}_{2} \mathrm{O}$ & 2.1 & 1.9 & 2.8 & 2.5 & 4.6 \\
\hline $\mathrm{P}_{2} \mathrm{O}_{5}$ & 0.2 & 0.0 & 0.0 & 0.0 & 0.0 \\
\hline$\Sigma$ & & 67.2 & & 55.1 & \\
\hline \multicolumn{6}{|c|}{ Normative composition } \\
\hline Component & wt. \% & & wt. \% & & wt. \% \\
\hline Qtz & 13.6 & & 18.7 & & 36.4 \\
\hline Or & 12.4 & & 16.8 & & 27.2 \\
\hline $\mathrm{Ab}$ & 21.2 & & 29.1 & & 24.5 \\
\hline An & 23.5 & & 32.4 & & 10.7 \\
\hline Di & 8.9 & & 0.9 & & - \\
\hline Hyp & 15.2 & & - & & - \\
\hline Mgt & 3.5 & & - & & - \\
\hline Ilm & 1.3 & & - & & - \\
\hline Ap & 0.5 & & - & & - \\
\hline
\end{tabular}

Table 2. Oxide content for diopside.

\begin{tabular}{|c|c|c|c|}
\hline Oxide & $\boldsymbol{M}_{\mathbf{0 x}}$ & $\boldsymbol{M}_{\mathbf{0 x}} \boldsymbol{M}_{\mathbf{D i}}$ & $\left(\boldsymbol{M}_{\mathbf{0 x}} / \boldsymbol{M}_{\mathbf{D i}}\right) \times \mathbf{8 . 9} \%$ \\
\hline $\mathrm{CaO}$ & 56.1 & 0.26 & 2.3 \\
\hline $\mathrm{MgO}$ & 40.3 & 0.19 & 1.7 \\
\hline $2 \mathrm{SiO}_{2}$ & 120.2 & 0.55 & 4.9 \\
\hline
\end{tabular}

The oxide content of hyperstene (Hyp $=15.2 \%$ ) is determined using the same procedure as for Di. Hyperstene has the formula $(\mathrm{Mg}, \mathrm{Fe})_{2} \mathrm{Si}_{2} \mathrm{O}_{6}(\mathrm{Fe}=50 \%)$, and in the form of oxides $\mathrm{MgO} \cdot \mathrm{FeO} \cdot 2 \mathrm{SiO}_{2}\left(M_{\mathrm{Hyp}}=232.3\right)$. Similarly, the oxide content is determined for $\mathrm{Imm}\left(\mathrm{FeO} \cdot \mathrm{TiO}_{2}, 1.3 \%\right)$ and for $\mathrm{Mgt}\left(\mathrm{FeO} \cdot \mathrm{Fe}_{2} \mathrm{O}_{3}, 3.5 \%\right)$. The total content for each oxide is the following: $\mathrm{SiO}_{2}=12.1 \%, \mathrm{FeO}=6.4 \%, \mathrm{Fe}_{2} \mathrm{O}_{3}=2.4 \%, \mathrm{CaO}=2.3 \%$, $\mathrm{MgO}=4.3 \%, \mathrm{TiO}_{2}=0.7 \%$. The settled $\mathrm{RM}$, which form the lower layer of the plume head (Fig. 1A) comprise in aggregate $29.4 \%$ (Table 1, column 2). For melt remaining after the settling of RM we have normative composition given in Table 1, column 2. For a system of spheres, approximately $26 \%$ of melt remains in the intercrystalline space of the layer composed of crystallites (as a first approximation, spherical particles) of RM. The indicated weight content is $0.26 \times 29.4=7.6 \%$. Then the weight percentage of each melt component is multiplied by 0.076 . For example, $\mathrm{Qtz}\left(\mathrm{SiO}_{2}\right)=0.076 \times 13.6 \%=1.0 \%$. For the other components we have: orthoclase $\mathrm{Or}\left(\mathrm{K}_{2} \mathrm{O} \cdot \mathrm{Al}_{2} \mathrm{O}_{3} \cdot 6 \mathrm{SiO}_{2}\right)=1.0 \%$, albite $\mathrm{Ab}$ $\left(\mathrm{Na}_{2} \mathrm{O} \cdot \mathrm{Al}_{2} \mathrm{O}_{3} \cdot 6 \mathrm{SiO}_{2}\right)=1.6 \%$, and anorthite $\mathrm{An}\left(\mathrm{CaO} \cdot \mathrm{Al}_{2} \mathrm{O}_{3} \cdot 2 \mathrm{SiO}_{2}\right)=1.8 \%$. 
The total oxide content in the intercrystalline space can be determined using the above procedure. For oxides we obtain: $\mathrm{SiO}_{2}=3.3 \%, \mathrm{Al}_{2} \mathrm{O}_{3}=1.1 \%, \mathrm{CaO}=0.4 \%$, $\mathrm{Na}_{2} \mathrm{O}=0.2 \%, \mathrm{~K}_{2} \mathrm{O}=0.2 \%$. We found the sum of the contents of each oxide for settled minerals and melt in the intercrystalline space: $\mathrm{SiO}_{2}=15.4 \%, \mathrm{TiO}_{2}=0.7 \%$, $\mathrm{Al}_{2} \mathrm{O}_{3}=1.1 \%, \mathrm{Fe}_{2} \mathrm{O}_{3}=2.4 \%, \mathrm{FeO}=6.4 \%, \mathrm{MgO}=4.3 \%, \mathrm{CaO}=2.7 \%, \mathrm{Na}_{2} \mathrm{O}=0.2 \%$, $\mathrm{K}_{2} \mathrm{O}=0.2 \%, \mathrm{P}_{2} \mathrm{O}_{5}=0.2 \%$. Then, in terms of oxides, the overall content of the solid phase and the melt in the intercrystalline space comprises $33.6 \%$. Hence, one can evaluate the thickness of the melt layer $l_{\text {melt }}$ overlain the settled RM: $l_{\text {melt }}=l(1-0.336)=0.664 l$.

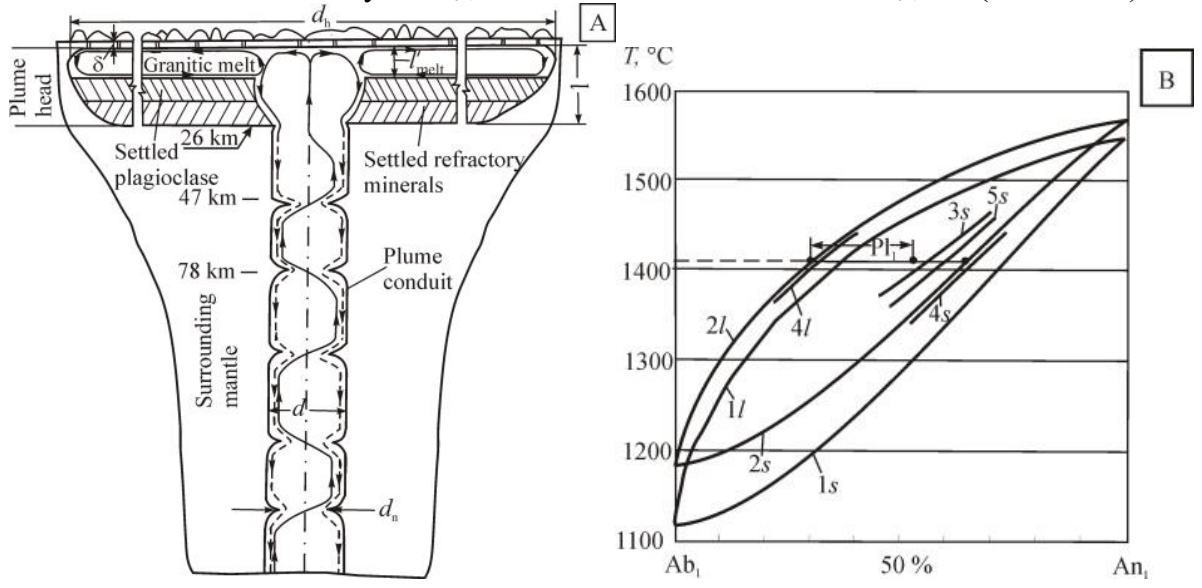

Fig. 1. The influence of crystallization differentiation on the plume head composition and structure. (A) Schematic of the plume with the mushroom-shaped head. The plume conduit diameter is $d=29$ $\mathrm{km}$ (Khentei plume, North-Eastern Mongolia). (B) Phase diagram of plagioclase feldspars for different pressures. Solidus and liquidus lines are denoted by $\mathrm{s}$ and 1 , respectively. The numerals relate to the pressures: 1 to $\mathrm{P}=1 \mathrm{bar}$ [3], 2 to $6.3 \mathrm{kbar}, 3$ to $12 \mathrm{kbar}, 4$ to $5 \mathrm{kbar}, 5$ to $10 \mathrm{kbar}$.

For the plume head of thickness $l=d=29 \mathrm{~km}$ (Khentei plume, Fig. 1A), $l_{\text {melt }}=19.3 \mathrm{~km}$. We subtract the percent composition of the corresponding deposited oxide (with regard to the melt in the intercrystalline space) from the bulk composition of continental crust. Then we obtain the percent composition of residual melt (Table 1, column 3). Let us determine the oxide content of the melt layer of thickness $l_{\text {melt }}$. In Table 1 we determine the sum of column $3\left(\sum=67.2 \%\right)$ and further multiply it by the ratio 100/67.2. The composition of the melt layer (in the oxide form) is presented in Table 1 (column 4). The corresponding normative composition is also presented in column 4. The normative quartz (Qtz, 18.7 \%) occurs in the melt as the suspended solid.

Let us determine the composition of the melt of thickness $l_{\text {'melt }}$, which remains after settling of plagioclase crystallites (Fig. 1A). Plagioclase (Pl) consists of a solid solution between the albite and anorthite end-members. The content of the plagioclase component in the residual melt is evaluated using the phase diagram of the system $A b_{1}-A n_{1}$, where $\mathrm{Ab}_{1}=\mathrm{Ab} /(\mathrm{Ab}+\mathrm{An}), \mathrm{An}_{1}=\mathrm{An} /(\mathrm{Ab}+\mathrm{An}), \mathrm{Ab}$ is the content of albite, An is that of anorthite of the crustal layer subjected to melting (Fig. 1B). As a first approximation, it is assumed that the behavior of the phase diagram $A b_{1}-A_{1}$ is unaffected by the presence of orthoclase component $(16.8 \%)$ in the melt. As indicated in our previous paper [1], the plume head is modeled by the flat liquid layer. The temperature of melt in the plume head is constant accurate to $0.2^{\circ} \mathrm{C}$. Thus, at the melt temperature of $1410^{\circ} \mathrm{C}$ the crystallized plagioclase occurs in relatively isothermal conditions. However, the crystallized plagioclase occurs in unstable state in the gravity field because of the density difference between the melt and the crystallized plagioclase. For example, considering the density of albite $\left(2.6 \mathrm{~g} / \mathrm{sm}^{3}\right)$ and anorthite $\left(2.75 \mathrm{~g} / \mathrm{sm}^{3}\right)$ for plagioclase N 30 containing $30 \% \mathrm{An}_{1}$ (Fig. 1B, the solidus line) 
$\rho_{1}=2.65 \mathrm{~g} / \mathrm{sm}^{3}$, whereas for plagioclase $\mathrm{N} 70$ containing $70 \% \mathrm{An}_{1}$ (Fig. 1B, the liquidus line) $\rho_{2}=2.71 \mathrm{~g} / \mathrm{sm}^{3}$. The density difference is $\Delta \rho=\rho_{2}-\rho_{1}=0.06 \mathrm{~g} / \mathrm{sm}^{3}$, that is, the density contrast is $2.2 \%$. The settling of solid particles of plagioclase proceeds under the conditions of horizontal free-convection flows [1]. Since heat is removed from the base of the plume head, with increasing pressure, that is, going toward the base of the plume head the melt becomes enriched with the crystallized plagioclase. The quantity of the crystallized plagioclase is determined under the following conditions: $P_{\mathrm{b}}=6.3 \mathrm{kbar}$ and $T_{\text {melt }}=1410{ }^{\circ} \mathrm{C}$. The plagioclase composition corresponds to $\mathrm{N} 65$, while the melt composition corresponds to $\mathrm{N} 30$ (Fig. 1B). The percent composition of the crystallized plagioclase is the following: $\mathrm{Ab}_{\text {cryst }}=\mathrm{Ab}_{1 \text { cryst }}(\mathrm{Ab}+\mathrm{An}) \mathrm{Pl}_{1 \text { cryst }}=35 \% \times 0.615 \times 0.65=14 \%, \mathrm{An}_{\text {cryst }}=\mathrm{An}_{1 \text { cryst }}(\mathrm{Ab}+$ $\mathrm{An}) \mathrm{Pl}_{1 \text { cryst }}=65 \% \times 0.615 \times 0.65=26 \%$. For the settled plagioclase we have $\mathrm{Pl}_{1 \text { cryst }}\left(\mathrm{Ab}_{\text {cryst }}+\mathrm{An}_{\text {cryst }}\right)=0.65 \times 61.5 \%=40 \%$. The quantity of melt which remains with the settled plagioclase (in the intercrystalline space) is $0.26 \times 40 \%=10.4 \%$. Then the weight percentage of each melt component is multiplied by 0.104 . For example, the melt in the intercrystalline space contains $\mathrm{Qtz}=0.104 \times 18.72=2.0 \%$. Similarly, Or $=1.8 \%$, $\mathrm{Ab}=1.6 \%$, and $\mathrm{An}=0.7 \%$.

The oxide content of the settled plagioclase is determined using the procedure described above at the first stage of calculations. Then the total oxide content of the settled plagioclase and melt in the intercrystalline space is determined. The fraction of the solid phase and melt in the intercrystalline space comprises 0.44 . The thickness of the residual melt layer $l_{\text {melt }}^{\prime}$ (Fig. 1A) is equal to $l_{\text {melt }}^{\prime}=(1-0.44) l_{\text {melt }}=0.56 l_{\text {melt }}$. For $l_{\text {melt }}=19.3 \mathrm{~km}$, $l^{\prime}$ melt $=10.8 \mathrm{~km}$. The oxide content of the residual melt (Table 1, column 6) is calculated using the procedure identical to that for the melt composition after the settling of RM. The $\mathrm{SiO}_{2}$ content is $76.1 \%$. The $\mathrm{SiO}_{2}$ content of normal granites is $70-73 \%$ [4]. The normative composition of the melt is also presented in the Table 1 (column 6). The normative contents of albite and anorthite are $\mathrm{Ab}=24.5 \%$, and $\mathrm{An}=10.7 \%$. The normative calculations for the normal granites [4] show that the albite content is $\mathrm{Ab}=15-19 \%$ and the anorthite content is $\mathrm{An}=1-9 \%$. These values agree with our calculations for the melt components.

\section{Summary}

Our calculations for the components of the residual melt in the plume head agree with the normative calculations for the normal granites. The $\mathrm{SiO}_{2}$ content of the residual melt is $76.1 \%$. It is in agreement with the $\mathrm{SiO}_{2}$ content of normal granites. Thus, relying on the proposed model of the plume with the mushroom-shaped head the normative composition of the melt complying with the composition of normal granites has been obtained.

The work was supported by state assignment project No. 0330-2016-0016.

\section{References}

1. A.G. Kirdyashkin, A.A. Kirdyashkin, V.V. Gurov, MATEC Web of Conferences (this issue)

2. G.V. Voitkevich, A.V. Kokin, A.E. Miroshnikov, V.G. Prokhorov, Handbook on Geochemistry (Nedra, Moscow, 1990) [in Russian]

3. N.L. Bowen, Amer. J. Sci., 35, 577 (1913)

4. G.M. Saranchina, N.F. Shinkarev, Petrography of Magmatic and Metamorphic Rocks (Nedra, Leningrad, 1967) [in Russian] 